\title{
ANALISIS VALIDASI PENGEMBANGAN ANGKET MINAT SISWA TERHADAP PROSES PEMBELAJARAN MATEMATIKA
}

\author{
Nihayatus Sa'adah \\ S1 Pendidikan Matematika, Fakultas Ilmu Pendidikan, Universitas Hasyim Asy’ari \\ nihayatussaadah@unhasy.ac.id
}

\begin{abstract}
Abstrak
Penelitian ini bertujuan untuk menghasilkan produk berupa angket minat siswa terhadap proses pembelajaran matematika yang valid. Proses ini mengacu pada model pengembangan Plomp yang terdiri dari tiga tahap yaitu penelitian awal, pengembangan, dan penilaian. Namun, dalam penulisan ini penelitian hanya difokuskan pada proses validasi yang dilakukan oleh dua orang dosen dosen Pendidikan Matematika di Universitas Negeri Yogyakarta yang bertindak sebagai validator. Sebelum dinilai, produk beberapa kali direvisi agar didapat produk yang siap dinilai. Hasil validasi produk dari kedua validator dirata-rata mendapatkan nilai 30. Nilai tersebut jika dikonversikan ke skala kualitatif didapat bahwa kualitas produk yang dihasilkan sangat valid.

Kata kunci: Angket minat terhadap proses pembelajaran matematika, Hasil validasi
\end{abstract}

\begin{abstract}
This study aimed to produce a valid questionnaire about the students' interest to mathematics learning process. This process referred to Plomp's development model which consist of three steps: preliminary research, development or prototyping, and assessment. But, this article was focused on the validation process which held by two Mathematics Education lectures at Yogyakarta State University whom acted as validators. Before it was examined, this product got revised several times to get valuable product. The mean of validation scores from two validators was 30. If that score was converted to quantitative scale, it was produced very valid product.

Keywords: Questionnaire about students' interest to mathematics learning process, Validation result
\end{abstract}

\section{PENDAHULUAN}

Sekolah, sebagai sarana agar manusia bisa mendapatkan pendidikan yang lebih baik, harus bisa membekali siswa-siswanya dengan ilmu pengetahuan yang relevan dengan kondisi di masa depan. Salah satu mata pelajaran yang diajarkan di jenjang sekolah adalah matematika. Dalam setiap proses pembelajaran matematika di sekolah, guru telah merancang satu atau beberapa tujuan pembelajaran sebelum dilaksanakannya proses pembelajaran dan nantinya diharapkan seluruh siswa bisa mencapai tujuan tersebut di akhir proses pembelajaran.

Kosasih (2014) menyebutkan bahwa untuk mencapai tujuan pembelajaran yang telah ditetapkan, proses pembelajaran harus dirancang dengan memenuhi prinsip-prinsip yaitu berpusat pada siswa; menyediakan bermacam-macam pengalaman belajar melalui penerapan berbagai strategi dan model pembelajaran; bermuatan nilai, etika, dan estetika sehingga pembelajaran bisa menyenangkan, kontekstual, dan bermakna. Dengan adanya pembelajaran yang menyenangkan, kontekstual, dan bermakna diharapkan mampu menarik minat siswa sehingga tercapai tujuan pembelajaran.

Berkaitan dengan minat dalam proses pembelajaran matematika di kelas, Nitko \& Brookhart (2011) memberi contoh: ketika siswa merasa senang menyelesaikan masalah-masalah matematika yang diberikan oleh guru, maka perasaan tersebut merupakan salah pertanda bahwa siswa ini memiliki minat terhadap pembelajaran matematika. Adanya minat terhadap pembelajaran matematika merupakan satu modal awal yang harus dimanfaatkan oleh guru agar bisa tercapai tujuan pembelajaran.

Minat merupakan salah satu variabel afektif (nonkognitif) yang artinya hanya bisa diukur dengan instrumen nontes. Oleh karena itu, untuk mengetahui seberapa besar minat siswa terhadap proses pembelajaran di 
kelas, guru memerlukan suatu instrumen nontes yang tepat. Instrumen tersebut adalah angket. Menurut Retnawati (2016), angket adalah beberapa pernyataan yang diberikan kepada responden dalam bentuk tertulis.

Supaya layak digunakan, angket yang telah dikembangkan harus memenuhi syarat kevalidan terlebih dahulu. Angket yang valid akan dapat memberikan data yang tepat sesuai dengan apa yang akan diukur. Berdasarkan uraian di atas, maka rumusan masalah pada penelitian ini adalah "bagaimana kevalidan angket minat siswa terhadap proses pembelajaran matematika?"

\section{METODE}

Penelitian ini merupakan penelitian pengembangan (developmental research) yang mengacu pada model Plomp (2013). Model ini terdiri dari tiga tahap yaitu (1) penelitian awal, (2) pengembangan, (3) penilaian. Proses validasi dilakukan oleh dua orang dosen Pendidikan Matematika di Universitas Negeri Yogyakarta sehingga akan menghasilkan data berupa skor penilaian. Dalam menilai, validator akan memberikan skor antara 1 sampai 5 dengan arti skor 1 bila produk dan instrumen penilaian tidak baik kualitasnya, skor 2 bila produk dan instrumen penilaian kurang baik kualitasnya, skor 3 jika produk dan instrumen penilaian cukup baik kualitasnya, skor 4 jika produk dan instrumen penilaian baik kualitasnya, atau skor 5 jika produk dan instrumen penilaian sangat baik kualitasnya.

Selanjutnya, data tersebut dianalisis secara deskriptif kualitatif. Pada penelitian ini, skor rata-rata yang didapat dari dua validator akan dikonversi ke skala kualitatif dengan ketentuan sebagai berikut:

Tabel 1. Konversi Skor Angket

\begin{tabular}{|c|c|}
\hline Interval & Kriteria \\
\hline$x<23$ & Sangat valid \\
\hline $18<x \leq 23$ & Valid \\
\hline $13<x \leq 18$ & Sedang \\
\hline $8<x \leq 13$ & Tidak valid \\
\hline$x \leq 8$ & Sangat tidak valid \\
\hline
\end{tabular}

Keterangan: $x=$ skor rata-rata dari dua validator

\section{HASIL PENELITIAN}

Angket minat yang dimaksud dalam penelitian ini adalah angket yang dapat digunakan untuk mengukur minat siswa terhadap proses pembelajaran matematika di kelas. Angket minat disusun dengan terlebih dahulu melakukan studi pustaka guna menentukan definisi konseptual dari minat itu sendiri. Setelah terbentuk definisi konseptual selanjutnya diturunkan menjadi indikator kemudian dibuatlah butir-butir pernyataan angket minat. Angket minat dibuat dengan rincian tiga puluh butir pernyataan yang terdiri dari lima belas butir pernyataan positif (favorable item) dan lima belas butir pernyataan negatif (unfavorable item).

\section{Studi Pustaka}

Menurut Stipek (Woolfolk, 2007: 384), "interest increase when students feel competent, so even if students are not interested in a subject or activity, they may develop interest as they experience success." Pendapat ini menyebutkan bahwa minat siswa dapat ditingkatkan. Jika seorang siswa pada mulanya kurang atau tidak berminat terhadap proses pembelajaran matematika, apabila gurunya dapat menciptakan proses pembelajaran yang dapat memberikan siswa tersebut pengalaman yang membanggakan, minat siswa tersebut bisa meningkat. Senada dengan pendapat sebelumnya, Woolfolk (2007) dan Elliot, dkk (2000) menyebutkan bahwa pembelajaran matematika dapat digunakan untuk meningkatkan minat siswa yaitu dengan mengaitkan matematika dengan masalah kehidupan nyata dan siswa diberi kesempatan untuk aktif berinteraksi selama proses pembelajaran matematika.

Collette \& Chiapetta (1994: 74) mengemukakan bahwa "interest is as curiosity of fascination for an idea or event that engages attention." Minat sejalan dengan rasa ingin tahu seseorang terhadap sebuah ide atau kegiatan yang berdaya tarik tinggi sehingga menumbuhkan perhatian terhadapnya. Pendapat tersebut serupa dengan Elliot et al (2000: 349), "interest is similar and related to curiosity." Minat serupa dan berkaitan dengan rasa ingin tahu seseorang. Selain itu, adanya minat juga dapat ditunjukkan dengan kecenderungan seseorang untuk melakukan aktivitas tertentu. Sax (1980: 473) menyatakan, 
"interest is preference for one activity over another." Minat adalah kecenderungan seseorang untuk memilih satu aktivitas dibandingkan aktivitas lainnya. Pendapat serupa disampaikan oleh Nitko \& Brookhart (2011: 430), "interests are preferences for specific types of activities when a person is not under external pressure". Minat merupakan kecenderungan terhadap suatu aktivitas tertentu ketika seseorang tidak berada di bawah tekanan dari luar.

Gable (1986: 9) menyatakan minat dapat dijelaskan melalui tiga hal yaitu tujuan, arah, dan intensitas. "The targets of interest are activities, the direction can be described as interested or disinterested, and the intensity can be labeled as high or low." Tujuan dari minat adalah aktivitas. Apabila seseorang memiliki minat tertentu akan suatu hal, dia akan menunjukkannya melalui suatu aktivitas yang dia lakukan. Arah dari minat adalah tertarik atau tidak tertarik. Apabila seseorang bisa memutuskan dia tertarik atau tidak terhadap suatu hal, itu artinya dia memiliki atau tidak memiliki minat terhadap hal tersebut. Sedangkan intensitas dari minat menunjukkan besaran minat yang dimilikinya, apakah tinggi atau rendah. Ketiga hal ini (tujuan, arah, dan intensitas) ini berkaitan satu sama lain. Jika seseorang berminat pada suatu aktivitas (tujuan minat telah diketahui), sudah bisa dipastikan arah minat dari aktivitas tersebut adalah tertarik dan intensitasnya tinggi, demikian pula sebaliknya.

\section{Definisi Konseptual Minat}

Dari beberapa pendapat ahli di atas, dapat disimpulkan bahwa minat adalah kecenderungan seseorang terhadap suatu objek atau aktivitas yang dapat membangkitkan perhatian dan rasa ingin tahunya. Dari definisi konseptual tersebut, didapat tiga aspek yang terdapat pada minat yaitu kecenderungan, perhatian, dan rasa ingin tahu. Dalam kaitannya dengan proses pembelajaran matematika, minat siswa terhadap proses pembelajaraan matematika dapat didefinisikan sebagai kecenderungan siswa terhadap matematika atau proses pembelajaran matematika yang dapat membangkitkan perhatian dan rasa ingin tahunya. Tiga aspek tersebut kemudian digunakan sebagai dasar untuk menyusun indikator dan butir pernyataan.

\section{Indikator Minat}

Adapun kisi-kisi angket minat siswa terhadap pembelajaran matematika dijabarkan pada berikut ini:

Tabel 2. Kisi-Kisi Angket Minat Siswa terhadap Pembelajaran Matematika

\begin{tabular}{|c|c|c|c|c|}
\hline \multirow{2}{*}{ Aspek } & \multirow{2}{*}{ Indikator } & \multicolumn{2}{|c|}{ Butir Pernyataan } & \multirow{2}{*}{ Jumlah } \\
\hline & & Positif & Negatif & \\
\hline \multirow{2}{*}{ Kecenderungan } & Menyukai pelajaran matematika & 15,8 & 6,26 & 4 \\
\hline & Mempersiapkan diri sebelum pelajaran & $7,21,25$ & $19,5,16$ & 6 \\
\hline \multirow{2}{*}{ Perhatian } & Bersikap serius & $3,28,14$ & $22,17,24$ & 6 \\
\hline & Disiplin & 30,23 & 2,13 & 4 \\
\hline \multirow{2}{*}{ Rasa Ingin Tahu } & Mencari sumber belajar lain & 1,12 & 27,4 & 4 \\
\hline & Mengerjakan soal matematika & $29,10,11$ & $9,18,20$ & 6 \\
\hline \multicolumn{2}{|r|}{ Jumlah } & 15 & 15 & 30 \\
\hline
\end{tabular}

Produk awal angket minat dikembangkan dengan cara mendaftar lima belas butir pernyataan positif baru selanjutnya disusun lima belas butir pernyataan negatif yang merupakan lawan dari butir-butir pernyataan positif. Penyusunan butir pernyataan diatur seluruhnya berupa opini siswa yang nantinya bisa diisi dengan pilihan sangat tidak setuju, tidak setuju, ragu-ragu, setuju, dan sangat setuju.
Setelah angket minat selesai dikembangkan menjadi produk awal, kemudian dinilaikan pada dua validator yaitu Validator 1 dan Validator 2. Langkah awal yang dilakukan ketika proses validasi adalah menyerahkan produk awal. Setelah dilakukan beberapa kali revisi atas produk awal yang dinilai, angket minat tersebut siap dinilai dengan menggunakan lembar validasi yang telah disusun sebelumnya. Adapun 
hasil proses validasi oleh para validator akan diuraikan pada Tabel 3 di bawah ini:

Tabel 3. Data Kevalidan Angket Minat

\begin{tabular}{|c|c|}
\hline Penilaian dari & Skor \\
\hline Validator 1 & 30 \\
\hline Validator 2 & 30 \\
\hline Rata-Rata & 30 \\
\hline
\end{tabular}

Berdasarkan Tabel 3 di atas dapat dilihat bahwa nilai rata-rata hasi validasi terhadap angket minat yang dikembangkan adalah 30. Nilai tersebut jika dikonversikan berdasarkan standar penilaian pada Tabel 1 , didapat hasil bahwa kualitas kevalidan angket minat yang dikembangkan adalah sangat valid.

Selain mendapatkan skor, pada proses penilaian juga didapat beberapa saran untuk perbaikan angket minat. Adapun hasil revisi oleh para validator akan diuraikan pada Tabel 4 di bawah ini:

\section{DAFTAR PUSTAKA}

Elliot, S.N., et al. 2000. Educational psychology: effective teaching, effective learning. Boston, MA: The McGrewHill Companies, Inc.

Gable, R.K. 1986. Instrument development in the affective domain. New York, NY: Springer Science+Business Media.

Kosasih. 2014. Strategi Belajar dan Pembelajaran Implementasi Kurikulum. Bandung: Yrama Widya.

Nitko, A.J. \& Brookhart, S.M. 2011. Educational Assesment of Students (6 $6^{\text {th }}$ ed). New York, NY: Pearson.

Plomp, T. 2013. Educational design research: an Introduction. Dalam T.
Tabel 4. Hasil Revisi Butir Pernyataan Angket Minat dari Validator

\begin{tabular}{|l|l|}
\hline \multicolumn{1}{|c|}{ Sebelum Revisi } & \multicolumn{1}{c|}{ Sesudah Revisi } \\
\hline $\begin{array}{l}\text { Saya lupa membawa } \\
\text { buku ke sekolah }\end{array}$ & $\begin{array}{l}\text { Saya lupa membawa } \\
\text { buku matematika ke } \\
\text { sekolah }\end{array}$ \\
\hline $\begin{array}{l}\text { Saya mengerjakan } \\
\text { soal jika ditugasi }\end{array}$ & $\begin{array}{l}\text { Saya mengerjakan } \\
\text { soal matematika jika } \\
\text { ditugasi }\end{array}$ \\
\hline $\begin{array}{l}\text { Saya mengikuti } \\
\text { pembelajaran } \\
\text { matematika dengan } \\
\text { senang hati }\end{array}$ & $\begin{array}{l}\text { Saya belajar } \\
\text { matematika dengan } \\
\text { senang hati }\end{array}$ \\
\hline
\end{tabular}

\section{SIMPULAN}

Berdasarkan hasil dan pembahasan pada uraian di atas, maka angket minat yang dikembangkan sudah memenuhi syarat kevalidan suatu produk dan layak untuk digunakan. Skor penilaian rata-rata dari dua orang validator yaitu 30 dengan kategori sangat valid.

Plomp \& N. Nieveen (Eds), Educational design research: part A. (hlm. 10-51). Enschede: SLO.

Retnawati, Heri. 2016. Analisis Kuantitatif Instrumen Penilaian (Panduan Peneliti, Mahasiswa, dan Psikometrian). Yogyakarta: Parama Publishing.

Sax, G. 1980. Principle of educational and psychological measurement and evaluation $\left(2^{\text {nd }} e d\right.$ ). California, CA: Wadsworth Publishing Company.

Woolfolk, A. 2009. Educational psychology $\left(10^{\text {th }} e d\right)$. Boston, MA: Pearson Education 